University of Michigan Law School

University of Michigan Law School Scholarship Repository

1920

\title{
Contracts for the Benefit of a Third Person in Michigan
}

Grover C. Grismore

University of Michigan Law School

Available at: https://repository.law.umich.edu/articles/1245

Follow this and additional works at: https://repository.law.umich.edu/articles

Part of the Contracts Commons

\section{Recommended Citation}

Grismore, Grover C. "Contracts for the Benefit of a Third Person in Michigan." Mich. L. Rev. 18 (1920):

318-20.

This Response or Comment is brought to you for free and open access by the Faculty Scholarship at University of Michigan Law School Scholarship Repository. It has been accepted for inclusion in Articles by an authorized administrator of University of Michigan Law School Scholarship Repository. For more information, please contact mlaw.repository@umich.edu. 
Contracts for the Benefit of a Third Person in Michigan.-In the recent case of Preston v. Preston the supreme court of Michigan had occasion to consider the question as to whether or not one for whose benefit a contract is made has any enforcible rights. The suit was one 'in Chancery, the donee plaintiff was an invalid, and every consideration of justice and equity demanded that she be given relief. The court had, however, to face the fact that in recent cases it had indicated its opinion to be that the third party beneficiary has no rights. In Modern Maccabees v. Sharp, (1910) 163 Mich. 449, 456 the court speaking through the late Justice Ostrander had said, "The general rule in this state is regarded as settled. I see no reason for saying that it is not the same in proceedings at law and in equity." Again in In re Bush's Estate, (1017) I99 Mich. 102, 196. Justice Kuhn, the writer of the opinion in the principal case, had said, "No serious claim is made that a promise made by one person to another for the benefit of a third-a stranger to the consideration-will support an action by the latter according to the law of this state." And at page 199, "But the situation before us is not merely a question of applying the remedy to the rights of the parties, but under the law as it existed at the time this claim was filed, the claimant had no rights arising out of the iransaction against the defending estate."

The court in its first opinion in the case, reported at 205 Mich. 646, took the position that the rule as above announced had been so far changed by Sec. 10, Chap. 12, Act No. 314, Pub. Acts 1915 (3 Mrch. Conp. Laws 1915, $\$$ 1236I) as to enable the donee beneficiary to maintain a suit in equity on the promise made for her benefit. That this view is untenable was shown in a note in a recent number of this review ( 18 Mrch. L. REv. 58) wherein the hope was expressed that a more satisfactory basis might be found for the holding. On rehearing, in an opinion recently filed but not yet reported, the court receded from the position originally taken and now supports its judgment on entirely different grounds. From a reconsideration of the evidence in the case it now finds as a fact that the promise was made directly to the 
plaintiff, although the consideration was furnished by plaintiff's mother who, according to the original finding, was the sole promisee. As a result of this interpretation of the evidence the court concludes that the flaintiff is a privy to the contract and as such entitled to maintain the suit on the ground that this is an exception to the rule denying a right of action to one for whose ben 'fit a contract is made. ( $175 \mathrm{~N}$. W. 266.)

It is quite obvious that the court in its conclusion has confused two questions which are essentially different. If the plaintiff was a party to the contract-a promisee-, as the court finds, then the case is not one involving a contract for the benefit of a third person at all in the sense in which that phrase is commonly employed, and it simply makes confusion worse confounded to say that it is an exception to the general rule. There is under these circumstances no want of privity in the plaintiff-the usual ground for denying relief in third party cases-and the only question involved is whether or not a party to a contract may enforce a promise made to him, the consideration for which was furnished by another. This question has always been answered in the affirmative in Michigan, both at law and in equity, and it has never been asserted that this holding at all conflicts with the rule denying the right of a third party beneficiary. Monaghan v. Agricultural Fire Ins. Co., 53 Mich. 238; Clark v. Clark, 134 Mich. 602 (semble); Palmer v. Bray, 136 Mich. 85 . This is in accord with the generally prevailing rule in this country. Van Eman v. Stanchfield, to Minn. 255; Rector v. Teed, 120 N. Y. 583; Palmer Savings Bark v. Ins. Co., 166 Mass. 189; Williamson v. Yoger, or Ky. 282. Contra: Dunlop v. Selfridge, [ro15] A: C. 847.

In view of the evident uncertainty in regard to the third party's rights it may be worth while to try to determine just what has been decided by the court. Where the action was one at law for breach of promise, the uniform holding has been that the third party has no enforcible rights, and this is true as well in the case of a sole or donee beneficiary as in the case of a creditor beneficiary. Pipp v. Reynolds, 20 Mich. 88; Turner v. McCarty, 22 Mich. 264; Halsted v. Francis, 31 Mich. II2; Hicks v. McGarry, 38 Mich. 667; Hidden v. Chappel, 48 Mich. 527; Edwards v. Clement, 81 Mich. 513; Wheeler v. Stewart, 94 Mich. 445; Linneman v. Moross, 98 Mich. 178; Signs v. Bush Estate, 199 Mich. 192 . But where the defendant has received specific funds to be delivered to the third party, it is held the latter may enforce the obligation in general assumpsit. Fay v. Anderson, 48 Mich. 259. It has also been held that a sole beneficiary to whom the promisee has assigned his rights under the contract may enforce the claim at law as assignee, and it is intimated that he may recover substantial damages. Ebcl v. Pichl, I34 Mich. 64. Such a result would, however, be difficult to justify in view of the fact that the ordinary rule would limit the recovery in such a case to nominal damages. See Burbank v. Gould, 15 Me. I18; Adans v. Union R. R. Co., 2r R. I. r34. Search has failed to disclose any suit in Chancery brought by the beneficiary, except that of a mortgagee beneficiary to be mentioned later, in which a decision of this question was necessary to dispose of the case. Modern Maccabees v. Sharp, supra, is not an exception to this statement for the reason that in that case the court apparently found as a fact that the 
promise sued on had not been made. See head note to the case. Assuming the alleged promise to have been made, it was clearly one which would only incidentally have benefitted the plaintiff and cannot therefore be said to have been made for his benefit. The court has, however, frequently expressed the opinion obiter either that relief in equity would be granted to the beneficiary or that the question is still an open one. See Limsteman v. Moross, 9 Mich. 178; Clare v. Warner, 106 Mich. 695; Palmer. v. Bray, 136 Mich. 8.. In Peer v. Kean, i4 Mich. 354. where A contracted with B on a consideration furnished by the latter to build a ship and on its completion to convey a one-half interest to B's wife upon payment by her of certain charges, the court granted specific performance of the promise at the suit of $B$, the promisee. Whether the same relief would have been granted at the suit of the wife was not indicated. The mortgagee beneficiary has always been granted relief in equity as against the grantee of the mortgaged premises who assumed the mortgage, but whether on the theory of subrogation or by reason of a statute (CoMp. I. I915 § 12680) the court has not always definitely indicated. Crawford v. Edwards, 33 Mich. 353; Miller v. Thompson, 34 Mich. 9; Corming v. Burton, 102 Mich. 86.

It is quite clear that the third party, at any rate where he is a sole or donee beneficiary, ought to be given relief. The cases show that parents as well as others frequently make provision in this way for those dependent upon their bounty. To deny the latter a remedy is to enrich the unscrupulous at the expense of the needy. While the rule of stare decis probably precludes the giving of relief in an action at law, the question is apparently still an open one in equity, and relief in the nature of specific perfnrmance would not seem to be inconsistent with equitable principles. Such a holding would make it unnecessary to strain the facts to do justice in a particular case. Perhaps legislative action on the matter would not be untimely. G. C. G. 